Available online: 20. October 2017

\title{
CHALLENGES OF WATER MANAGEMENT: CASE STUDY OF GRUŽA RESERVOIR
}

\author{
Snežana Vujadinović ${ }^{* 1}$, Dejan Šabić, Mirjana Gajićn \\ "University of Belgrade - Faculty of Geography, Belgrade
}

\begin{abstract}
The paper analyses the legal and institutional framework of water management in Serbia. The aim is to identify existing obstacles that interfere with the development and implementation of Integrated Water Resources Management (IWRM). The paper points out some of the most common challenges of integrated reservoir management in Serbia, such as gaps and ambiguities in the legislative framework, poor institutional coordination, underdeveloped environmental awareness and often conflicting stakeholder involvement. The case study is trying to address the current challenges of using and managing the water reservoir. The paper will provide answers to the following questions: What are the main problems related to the use and management of reservoirs, how to reconcile different sectors and users of the water resources, how to achieve the economic and environmental development goals?
\end{abstract}

Key words: integrated management of water, legislation, institutions, Serbia, Gruža lake, eutrophication, stakeholder, local government.

\section{Introduction}

Freshwater resources can become the most limited resource in the future due to the increasing consumption of water, climate change and degradation of aquatic ecosystems (Wiek and Larson, 2012). Artificial lakes are an

${ }^{1}$ Corresponding author:S. Vujadinović, University of Belgrade - Faculty of Geography, Studentski trg 3/III, 11,000 Belgrade, Serbia; e-mail: vujadinovicsnezana@gmail. com 
important ecological, economic and recreational resource. Theyhave many uses, including water supply, flood control, electricity generation, irrigation and recreation. The main disadvantages are the loss of the fertile agricultural land, displacement of people, changes in downstream flows and the impact on the migration of ichthyofauna and microclimate change.

Eutrophication is the main problem that disturbs the quality of water in reservoirs around the world (Schindler, 2012; Wu et al., 2012; Huo et al., 2013; Lürling et al., 2016; Wagner and Erickson, 2017; Li et al., 2017 Jeppesen et al., 2017). Many lakes are polluted to a great extent from concentrated and dispersed sources of pollution. The lake and its basin are fundamentally linked, and its potential long-term use is influenced by interactions between people, water and land resources. The human activities in the basin have large impact on water quality and lake functions. Most scientists agree that improved management will solve problems related to these resources (Araral and Wang, 2013). In the past, the management of water resources was focused on meeting the society's needs, while today the focus is on securing human needs and as well as the needs of an ecosystem.

The key issue for water management experts is how to best balance human needs and the needs of ecosystems. Reservoir management is becoming increasingly complex and dynamic due to rising tensions between opposing objectives. In addition to traditional aims such as control of floods, water supply, navigation and energy production, challenges also include preserving water quality, conserving habitats of endangered species and various recreational needs. Improper water management is often a failure of management. More precisely, it is the absence of adequate institutional framework for the management of freshwater ecosystems, water and water services. The principal aim of water management policy is to establish a balance between equality and efficiency in the distribution and use of water resources.

In order for the reservoirs to remain healthy ecosystems, many authors emphasize the need for a systematic and integrated approach to water management at the basin level (Allan, 2012). Integrated Water Resources Management (IWRM) is a process that promotes coordinated development and management of water resources (sectoral integration of development and management of water resources) in order to maximize economic and social protection without jeopardizing the sustainability of vital ecosystems and ensuring that water is distributed properly between different users (GWP, 2000). Adequate utilization of this approach enables a sustainable solution to water issues (Chidammodzi and Muhandiki, 2017; Schoeman et al., 2014). 
The basic idea of IWRM is to adopt a comprehensive, interdisciplinary and holistic approach to water resources issues, including their social, political, economic, technical and environmental aspects. Coordinated holistic water management is considered to be better than a single-sector approach, because it takes into account all water users in nature and society, thus harmonizing the use, development and management of water resources (Gain et al., 2013; Benson et al., 2012; al., 2015). The integration, both vertical (within the sector) and horizontal (between different sectors), is essential for effective management (Varis et al., 2014). IWRM is a systematic process of sustainable management, development, allocation and monitoring of water resources in order to find practical and sustainable solutions and achieve socio-economic and environmental goals (Cook and Spray, 2012; Gallego-Ayala, 2013; Grigg, 2014).

IWRM has a long history, during which positive and negative experiences were recorded (Varis et al., 2014). For example, in many countries its application has been a very slow process. The advantage of IWRM is that it provides a range of ideas that help us to holistically look at the water resources. On the other hand, IWRM has become an aim in itself, a global discourse on water management that often excludes pragmatic solutions to existing water problems (Giordano and Shah, 2014). IWRM will be successful only if it is multidisciplinary and if it uses all available knowledge and experience, both scientific and traditional (Perry, 2013). Successful IWRM also depends on the legal, regulatory and institutional ambience. Integrated Water Resources Management aims to find practical and sustainable solutions to water resources issues (Halbe et al., 2013).

This paper provides a detailed qualitative analysis of the legal basis, strategic documents and regulations. The aim is to identify the basic obstacles for the implementation of integrated water management in Serbia. Field survey data were collected with field observations, interviews with experts, local government bodies and local population, with the aim of pointing out practical problems in practice (case study).

\section{Methodological approach}

Proper water management in Serbia implies appropriate legislation, water infrastructure (utility and transport), planning and undertaking measures from local to state level. Each of these levels is specific in terms of physical-geographical and socio-economic characteristics, so adequate mechanisms must be found to ensure integrated and sustainable management of water resources. 
In accordance with the principles of the Water Framework Directive 2000/60 / EC, Serbia has significantly amended the legislation in the field of water management. Water management in Serbia takes place through the development and implementation of several planning documents(Water management strategy on the territory of the Republic of Serbia; Water management plan, plans for the protection against harmful effects of waters and plans for water protection). The water management strategy in the territory of the Republic of Serbia (Strategija upravljanja vodama na teritoriji Republike Srbije) is a key planning document that determines long-term water management goals.

Water resources policy is regulated by laws and other regulations. The Law on Waters ("Sl. glasnik RS" br. 30/10, 93/12 and 101/16) regulates water management in Serbia in accordance with EU legislation. In addition to the Law on Waters, there are a number of other laws that regulate water related issues to a lesser or greater extent: environmental laws (Law on Environmental Protection, Law on Strategic Environmental Assessment, Law on the Assessment of the Effects on Life Environment, Law on Integrated Prevention and Control of Environmental Pollution, Law on Waste Management, Law on Chemicals), Law on Public Enterprises and Performance of Activities of General Interest, Law on Local Self-Government, Law on Communal Activities, etc.

The institutional framework in Serbia for carrying out water management related issues includes: the Ministry of Agriculture, Forestry and Water Management, within which is the Republic Water Directorate, also the Ministry of Environment, Mining and Spatial Planning with the Environmental Protection Agency, the Provincial Secretariat for agriculture, water management and forestry of the autonomous province of Vojvodina, local self-government units and public water management companies (in the area of the autonomous province of Vojvodina - "VodeVojvodine" and the rest of the Republic of Serbia - public water management company "Srbijavode" and public water management company "Beogradvode"). The implementation of the annual monitoring program for surface water and groundwater quality from 2011 is carried out by the Environmental Protection Agency, a body within the Ministry of Environmental Protection.

The Ministry of Health, the Ministry of Education and Science, the Ministry of Public Administration and Local Self-Government, Republic Hydro Meteorological Service of Serbia, the Ministry of Infrastructure and Energy and the Ministry of Health have partial jurisdictions in the field of water management.

In the field of water management at the national level, numerous other institutions and organizations are present in all types of activities: Water 
Council, National Conference, Republic Agency for Spatial Planning, Environmental Protection Fund, Institute for Nature Conservation of Serbia, Accreditation Body of Serbia ATS), Republic Geodetic Authority, Scientific Research Organization (Public Health Institute "Dr Milan Jovanović-Batut", Institute for Biological Research "Dr Siniša Stankovic" and "Jaroslav Černi" Institute).

Serbia is one of the many countries in which an integrated approach to water resources management has been promoted, but not all the preconditions for its successful implementation have been created. The main obstacles to the implementation of the IWRM are gaps in the legislative framework, insufficient cooperation and coordination between ministries, agencies and public water management companies, transitional poverty, education, poor management and lack of people's awareness of water as a natural resource. The situation in water management in Serbia is still at an unsatisfactory level in terms of water supply, especially in terms of wastewater treatment. Solving wastewaters and water supply problems will require significant investments in the future (Bečelić-Tomin et al., 2015).

For water supply in Serbia there are 23 reservoirs with high dams that are being used. The most common problems related to the management of the reservoirs are: the use period of all reservoirs for water supply (mostly over 30 years), sanitary (economic and ecological) restrictions in the use of land in the basin, high threat to the quality of accumulated waters (eutrophication, lack of systems for sewage and wastewater disposal, inadequate maintenance of the system, bad management of the fish fund), financial increase of drinking water treatment due to poor quality of lake water, numerous ecological consequences, etc. (Dokmanović and Nikić, 2015). The coordination and cooperation between institutions and all involved parties is essential for the efficient management of reservoirs for water supply of the population. If adequate coordination and cooperation is missing, there is a conflict between stakeholders, which leads to endangering water quality and increasing the cost of water purification. Most of the accumulation management challenges are met at the local level where active water management takes place.

Although there are no universal solutions, the management of reservoirs in Serbia should rely on the following principles that can be adapted to local conditions:

- A harmonious relationship between people and nature is essential for the sustainable use of the reservoirs and the achievement of economic, social and environmental goals, 
- The basin of the lake is the basis for the planning and management of the lake,

- It is necessary to take a preventive approach to the causes of degradation of the lake,

- Lakes management policy should be based on science and available information,

- Research and management of reservoirs requires a multidisciplinary approach,

- Planning is an important step towards achieving sustainable use of the reservoir,

- Disputable issues arise due to competitive or conflicting needs and the use of water resources,

- Sustainable use and management of reservoirs requires the resolution of conflicts among competing users of water resources,

- The aim is increase the positive effects of reservoirs, and to avoid, alleviate or compensate the negative effects,

- It is important to implement an adequate governance model that fosters equality of users and ecosystems,

- Implementation of innovative financial mechanisms,

- Engaging all of the stakeholders is key to success,

- Equality, transparency, accountability, communication and diplomacy are crucial,

- Governance based on fairness, transparency and empowerment of all stakeholders,

- Data quality, resources and availability of information may vary widely at the local and national levels,

- Strengthening partnerships and mobilizing resources are essential for achieving efficient management of the reservoirs,

- Sustainable development and functioning of the reservoir should rely on postulates such as: common vision, shared resource, shared responsibility, common rights and risks, common benefit and costs. 


\section{Description of Study Area}

The basin of the reservoir Gruža is a protected source of drinking water of statesignificance. The reservoir of Gruža was created in 1984 by building a dam on the river Gruža. The reservoir has submerged arable land of the Gruža basin. Most of the lake (about 80\%) has a small depth (up to $10 \mathrm{~m}$ ) and characteristics of low, slow current resorvoir. During the dry summer months, the flow of water from the river Gruža is minimal, while the smaller tributaries dry up (Milinčić et al., 2013; Marinović et al., 2016). The reservoir has several positive effects such as the stabilization of the Gruža water level downstream of the accumulation and reduction of the flood risk, the water supply of the settlements as well as the possibility of limited valorization of the lake and its coastal area for recreational, sports and tourism purposes. The construction of the reservoir has solved the problem of water supply of the City of Kragujevac, 13 village settlements in the municipality of Knić and 6 settlements in the City of Kraljevo.

Table 1 - Basic data about Lake Gruža

\begin{tabular}{|l|l|}
\hline Surface Area $\left(\mathrm{km}^{2}\right)$ & 9.34 \\
\hline Volume $\left(\mathrm{m}^{3}\right)$ & $64.4 \times 10^{6}$ \\
\hline Maximum Depth $(\mathrm{m})$ & 31 \\
\hline Mean Depth $(\mathrm{m})$ & 6.3 \\
\hline Max. length $(\mathrm{km})$ & 10 \\
\hline Max. width $(\mathrm{km})$ & 2.8 \\
\hline Shore length $(\mathrm{km})$ & 42 \\
\hline Latitude & $43^{\circ} 55^{\prime} 34^{\prime \prime} \mathrm{N}$ \\
\hline Longitude & $20^{\circ} 40^{\prime} 42^{\prime \prime} \mathrm{E}$ \\
\hline Altitude & $238-269 \mathrm{~m}$ above sea level \\
\hline Normal range of annual water level fluctuation $(\mathrm{m})$ & $3-5$ \\
\hline Catchment Area & 318.2 \\
\hline Sanitary protection area $\left(\mathrm{km}^{2}\right)$ & 14.50 \\
\hline Primary inflow & Gruža River \\
\hline
\end{tabular}

Source: Pešić, 2012; Milinčić et al., 2013. 


\section{Results and discussion}

Reservoirs with the purpose of water supply require a high quality of water and ecosystems. Poor planning and management have led to the strong eutrophication of the Gruža reservoir, although the lake ecosystem is about thirty-three years old. The sewage system of the neighbouring settlements connected to the reservoir and industrial plants are the most significant concentrated sources of pollution. Disperse sources of pollution are difficult to identify and control, because in addition to septic tanks and unregulated municipal dump sites, there is also inadequate soil treatment, rinsing from forest and land surfaces, cattle fund, etc.

There is a large primary production of organic material and phytoplankton. Fecal pollution also speeds up the eutrophication process. High concentrations of phosphate were measured in the accumulation, also the occurrence of algae or cyanobacterial flowering in the summer period, when the level of water in the reservoir decreases. Occasional deficiencies of dissolved oxygen content (especially during the summer) have also been reported, as well as increased concentrations of manganese, ammonia, nitrite and iron (Ostojić et al., 2007). The most important causes of such state of the reservoir are:

- Inadequate ecological approach to the construction of the reservoir and unfavourable morphometric characteristics (large area of the lake and low volume of water),

- Deficiency regarding the legal framework,

- Failure to comply with existing legal regulations in practice,

- Insufficient cooperation between ministries, agencies, water management companies and local self-governments,

- Obsolescence or absence of planning documents,

- The lack of adequate sanitary protection in the basin of the reservoir as a source of water supply,

- Lack of interest of the local community towards the lake as a state good and water resource (illegal construction in the areas of sanitary protection of the reservoir, activities in fishing, recreation and sport in the accumulation zone, cultivation of land in areas of protection, etc. )

- Conflict between stakeholders and/or users

- Inconsistent application of polluter pays and user payprinciple 
Water regulations are present in laws relating to different uses, which complicates efficient water management and creates a chaotic situation with stakeholders when dealing with specific issues. The consequences of such failures in the legal framework are lawlessness, inefficiency, overlapping jurisdiction or fragmentation of water management. With regard to the organization of public authorizations, the Law on Waters is essentially centralist because local authorities have no jurisdiction in water management (Bečelić-Tomin et al., 2015; Dimkić et al., 2011). There is a lack of harmonization between Law on Waters and the Law on Local Self-Government and the Law on Communal Activities. The Law on Waters does not provide for any jurisdiction of local self-government units when it comes to systematic monitoring of water status and protected areas, supervision of sanitary protection zones, water management planning, etc.

In terms of usage and maintenance, the Gruža lake was treated only as a water reservoir, not as an ecosystem. Currently efforts are on the way to collect and share information on all lakes that will allow comparative analysis of trends. The lack of data for minor rivers or streams makes it difficult to manage reservoirs such as Gruža. Also, there must be mechanisms for controlling waste water, the use of fertilizers and pesticides. The level of consciousness and public participation in the efforts to preserve the lake, is still at very low level.

The construction of Gruža reservoir has created the conditions for its inclusion in the economic activation of the basin. However, integral and sustainable management of the Gruža reservoir is made difficult by the existence of the opposite interests of water management and the local community. The major challenge is to establish coordination between different sectors: water management (the primary function of the lake is the water supply of 250,000 inhabitants), agriculture (the basin of the lake is a homogeneous agrarian area), tourism (the local self-government sees tourism as one of the main development opportunities), fishing and other. The stakeholders have different concerns in relation to this water resource: water users and public water management companyVodovod from Kragujevac due to water quality; farmers because of the inability to use fertilizers and pesticides (agriculture is the main source of income for the local community), local selfgovernment due to illegal construction and waste, also the fishermen and excursionists have their concerns as well. While the common benefits of reservoir are indisputable, in practice, there are still many controversies regarding the optimal way to use the water resources. As a consequence, there are fierce accusations between local self-government, in this case Knić Municipality, in whose territory the reservoir is located and the main user of water 
resources - water management company Vodovod from Kragujevac. The following question arises: what model of management would be optimal for the Gruža reservoir, which would overcome the antagonism between the opposing sides and prevent further disturbance of water quality in the lake.

The field research has revealed numerous problems faced by the main stakeholders when it comes to the use and protection of the reservoir. Based on an analysis of opinions and perspectives of various parties included, the study has shown that the existing practice of using and managing the waters of the Gružareservoir is fragmented and inconsistent. If the ecological component of development is dominant, the local self-government sees lake as a ballast, a factor that restricts the development of agriculture and tourism; if the economic component of development is dominant, the local self-government perceivesreservoir as a factor of development primarily for tourism. Public water management companyVodovod-Kragujevac sees lake as a source of water supply and water quality is a priority for them.

Planning of water resources is the inseparable and the most important segment of spatial planning. This segment of spatial planning must precede all other planning, in order to define spatial requirements for the development of water management infrastructure. Adoption of a strategic document such as the Spatial Plan of the special purpose area of the Gruža reservoir basin, along with the existing Spatial Plan of theKnić municipality, will be an important contribution to spatial planning in the implementation of the legal framework of the Water Directive. These plans include the basic measures referred to in Article 11 of the Water Framework Directive: promoting efficient and sustainable water use, protecting water quality for the purpose of reducing the degree of purification required for the production of drinking water, controlling diffuse sources of pollution, prohibiting the direct release of pollutants in the groundwater, reducing pollution of surface waters, preventing or reducing the impact of accidental incidents that cause pollution.

\section{Conclusion}

Integrated water management is a long process and requires an appropriate legislative framework, as well as suitable institutional and organizational solutions. Serbia has made efforts to establish a legal and institutional framework for the integrated management of water resources. Although there is still a need to precisely define the rights and responsibilities of local communities, different institutions and enterprises. 
Without widespread public support in all activities addressing the problem of water use and protection, rational solutions cannot be found to ensure socio-economic development and environmental protection. Each reservoir is unique, and each process of reservoir management is a complex and responsible job that aims to protect and preserve the lake. Therefore, the management model needs to be adapted to the specific conditions.

The case study illustrates the gaps between the objectives of the IWRM promotion policy on the one hand and the realities associated with its practical implementation, on the other. Protection of the reservoir must be such that it maximally serves the basic purpose - water supply of the population, which means that it is not justified to favour other users who see reservoir as their interest, and at the same time they are endangering its basic purpose. Integrated and sustainable management of reserrvoirs implies the establishment of coordination and cooperation among different stakeholders; improving transparency and environmental awareness, effective local governance, through empowerment of the local community, etc. Otherwise, if the current trend continues, further degradation of water quality in the Gruža reservoir is expected, the cost of water purification is increased, and therefore a higher price for users.

\section{Acknowledgements}

The paper is the result of the research within the project no. 176008 funded by the Ministry of Education and Science of the Republic of Serbia.

\section{References}

Agencija za zaštitu životne sredine (2015). Status površinskih voda Srbije, Ministarstvo poljoprivrede i zaštite životne sredine, Beograd. Available from http://www.sepa.gov.rs/download/VodeSrbije/StatusPovrsinskihVoda Srbije.pdf

Allan, C. (2012). Rethinking the "project": Bridging the polarized discourses in IWRM. Journal of Environmental Policy and Planning, 14, 231-241.

Araral, E. and Wang, Y. (2013). Water Governance 2. 0: A Review and Second Generation Research Agenda. Water Resources Management, 27 (11): 3945-3957.

Benson, D., Jordan, A. and Huitema, D. (2012). Involving the public in catchment management: an analysis of the scope for learning lessons from abroad. Environmental Policy and Governance, 22 (1): 42-54. 
Benson, D., Gain, A. K. and Rouillard, J. J. (2015). Water governance in a comparative perspective: From IWRM to a 'nexus' approach? Water Alternatives, 8(1): 756-773.

Bečelić-Tomin, M., Dalmacija, B., Stanojević, D., Pešić, V., Krčmar, D., Kerkez, Đ. and Tomašević, D. (2015). Current and planned activities in the field of water management in Serbia. International Journal of Sanitary Engineering Research, 9(1):14-20.

Cook, B. R. and Spray, C. J. (2012). Ecosystem services and integrated water resource management: Different paths to the same end? Journal of Environmental Management, 109, 93-100.

Chidammodzi, C. and Muhandiki, V. (2017). Water resources management and Integrated Water Resources Management implementation in Malawi: Status and implications for lake basin management. Lakes \& Reservoirs: Research \& Management, 22(2): 101-114.

Dimkić, M., Milovanović, M. and Dimkić, D. (2011). Sustainable and Adaptive Water management: Case Study of Water Management in Serbia, Water Research and Management, 1(4): 9-19.

Directive 2000/60/EC of the European Parliament and of the Council of 23 October 2000 establishing a framework for Community action in the field of water policy. Available from http:/ / eur-lex.europa.eu/legal-content/ HR/TXT/PDF/?uri=CELEX:32000L0060\&from $=E N$

Dokmanović, P. i Nikić, Z. (2015). Analiza (ne)održivosti aktuelne strategijevodosnabdevanja u Srbiji. Tehnika, 70(3), 433-441.

Gain, A. K., Rouillard, J. J. and Benson, D. (2013). Can integrated water resources management increase adaptive capacity to climate change adaptation? A critical review. Journal of Water Resource and Protection, 5(4A), 11-20.

Gallego-Ayala, J. (2013). Trends in integrated water resources management research: A literature review. Water Policy, 15, 628-647.

Giordano, M. and Shah, T. (2014). From IWRM back to integrated water resources management. International Journal of Water Resources Development, 30(3): 364-376.

Grigg, N. S. (2014). Integrated water resources management: Unified process or debate forum? International Journal of Water Resources Development, $30,409-422$. 
Halbe, J., Pahl-Wostl, C., Sendzimir, J. and Adamowski, J. (2013). Towards adaptive and integrated management paradigms to meet the challenges of water governance, Water Science Et Tehnology, 67(11): 2651-2660.

Huo, S., Ma, C., Xi, B., Su, J., Zan, F., Ji, D. and He, Z. (2013). Establishing Eutrophication Assessment Standards for Four Lake Regions, China. Journal of Environmental Sciences, 25, 2014-2022.

Integrated Water Resources Management, Technical Advisory Committee Background Paper No. 4, (Stockholm, Global Water Partnership,2000). Available from http:/ / www.gwp.org/en/About/why/the-need-for-anintegrated-approach/

Jeppesen, E., Sondergaard, M. and Liu, Z. (2017). Lake Restoration and Management in a Climate Change Perspective: An Introduction. Water, 9 (2), 122.

Li, T.,Chu, C., Zhang, Y., Ju, M. and Wang, Y. ( 2017). Contrasting Eutrophication Risks and Countermeasures in Different Water Bodies: Assessments to Support Targeted Watershed Management. Int. J. Environ. Res. Public Health, 14(7), 695.

Lürling, M., Mackay, E. B.,Reitzel, K. and Spears, B. M. (2016). Editorial - A critical perspective on geo-engineering for eutrophication management in lakes. Water Res. 97, 1-10.

Marinović, Z., Lujić, L., Bolić-Trivunović, V. and Marković, G. (2016). Al Comparative study of growth in Carassiusgibelio (Bloch, 1782) and Rutilusrutilus (L., 1758) from two Serbian reservoirs: Multi-model analysis and inferences. Fisheries Research, Vol. 173, Part 1, 11-19.

Milinčić, M., Vujadinović, S., Ćurčić, N. and Šabić, D. (2013). Effects of Geoecological Factors on Vegetation of the Gruža Basin, Serbia, Archives of Biological Science 65(1), 121-132.

Ostojić, A., Ćurčić, S., Čomić, Lj. and Topuzović, M. (2007). Effects of anthropogenic influences on the trophic status of two water supply reservoirs in Serbia. Lakes \& Reservoirs: Research EManegement, 12(3), 175-185.

Perry, C. (2013). ABCDE+ F: A framework for thinking about water resources management. Water International, 38(1), 95-107.

Pešić, S. (2012). Aquatic weevil (Coleoptera: Curculionoidea) assembly response to the different ecological conditions in artificial lakes in Central Serbia. Arch. Biol. Sci., 64 (4), 1523-1531. 
Prostorni plan područja posebne namene sliva akumulacije Gruža (Odluka o izradi Sl. glasnik RS 44/11). Available from http://www.rapp.gov. rs/sr-Latn-CS/ akumulacije/cid320-83206/ prostorni-plan-podrucjaposebne-namene-sliva-akumulacije-gruza

Prostorni plan opštine Knić (Opštinski službeni glasnik br. 5/2011). Available from http://195.222.96.93:4000/system/files/1268/original/Prostorni_ plan_opstine_Knic_pdf_.pdf

Schindler, W. D. (2012). The dilemma of controlling cultural eutrophication of lakes. Proc. Biol. Sci., 279(1746): 4322-4333.

Schoeman, J., Allan, C. and Finlayson, C. M. (2014). A new paradigm for water? A comparative review of integrated, adaptive and ecosystem-based water management in the Anthropocene. International Journal of Water Resources Development, 30(3): 377-390.

Strategija upravljanja vodama na teritoriji RepublikeSrbije do 2034. godine (2016). Vlada Republike Srbije, Beograd). Available from http://www. rdvode.gov.rs/doc/Strategija_FINAL.pdf

Schmidt, J. J. (2013). Integrating Water Management in the Anthropocene. Society and Natural Resources, 26, 105-112.

Varis, O., Konrad, E. and Keskinen, M. (2014). Integrated water resources management: horizontal and vertical explorations and the 'water in all policies' approach. International Journal of Water Resources Development, 30(3):433-444.

Wagner, T. and Erickson, L. (2017). Sustainable Management of Eutrophic Lakes and Reservoirs. Journal of Environmental Protection, 8, 436-463.

Wiek, A. and Larson, K. I. (2012). Water, people and sustainability - A systems framework for analysing and assessing water governance regimes. Water Resources Management,26(11): 3153-3171.

Wu, F., Zhang, J. Y., Deng, X. Z. and Ling, Y. Z. (2012). Influencing factors of lake eutrophication in China. Ecol. Environ. Sci., 21, 94-100.

Zakon o vodama („Sl. glasnik RS”, br. 30/2010, 93/2012 i 101/2016).

Zakon o zaštiti životne sredine („Sl. glasnik RS”, br. 135/2004, 36/2009, 36/2009- dr. zakon, 72/2009 - dr. zakon, 43/2011-odluka US I 14/2016).

Zakon o lokalnoj samoupravi („Sl. glasnik RS”, br. 129/2007, 83/2014 - dr. zakoni 101/2016 - dr. zakon).

Zakon o komunalnim delatnostima („Sl. glasnik RS”, br. 88/2011 i 104/2016).

Zakon o javnim preduzećima („Sl. glasnik RS”, br. 15/2016). 